\title{
SOCIAL CONDITIONALITY OF CRIMINAL LIABILITY OF CRIMES AGAINST PERSON'S HEALTH
}

\section{Katerynchuk K. V.}

\section{INTRODUCTION}

Development of Ukraine as sovereign, independent, democratic, social and law-governed state requires regulation of certain public relations through the prism of law. It is the adoption of criminal-legal norms that is the evidence of the fact that the state, from the point of view of social necessity, makes decisions to impose some socially dangerous bans. The first step (stage) of criminal-legal norm "birth" is its conditionality, namely, factors being the recondition of further criminalization of one or another action, resulted in appropriate consolidation of the norm in regulatory legal act such as the Criminal Code of Ukraine.

Legal imposition of new criminal-legal bans has to be reasonable, scientifically justified and meets the needs of society development ${ }^{1}$. A mechanism of social conditionality of law includes the following stages:

- Emergence of the necessity to regulate certain relations legally;

- Public opinion formation and the activity of state competent authority on legal norm adoption - law-making activity. That is why "... one should understand under the social conditionality of law the compliance, adequacy of law to public relations regulated, its ability to reflect objective needs of public life. The property of social conditionality of law is expressed in the fact that, first of all, the law should be a dynamic system, reacting tactfully to the changes in social reality"2. For example, M. J. Korzhansky stated that "social conditionality of criminallegal protection is determined, in general, by social worth of public relations, economic factors and by the efficiency of legal protection" ${ }^{3}$.

\footnotetext{
${ }^{1}$ Теорія держави і права. Академічний курс: підручник / за ред. О. В. Зайчука, Н. М. Оніщенко. 2 вид., перероб. і допов. Київ: Юрінком Інтер, 2008. 688 c. URL: http://www.ebk.net.ua/Book/law/ zaychuk_tdp/part2/401.htm.

${ }^{2}$ Соціологія: підручник / Н. П. Осипова, В. Д. Воднік, Г. П. Клімова та ін.; за ред. Н. П. Осипової. Київ: Юрінком Інтер, 2003. 336 c. URL: http://radnuk.info/pidrychnuku/sotsiologiya/507-osupova/10927-s-2html/

${ }^{3}$ Коржанский Н. Й. Установление вины. Юрид. практика. 1997. № 3 (37). Февраль. С. 5-6.
} 
A lawmaker should possess information about a status, structure and dynamics of law offences and crimes, damages caused by them as well as other information necessary to solve the issue on criminalization of socially dangerous deeds ${ }^{4}$. That is why the next stage is "criminalization" of deed "... the determination of deed as a socially dangerous, guilty and punishable in the law on criminal liability"5; "the declaration of certain socially dangerous deeds as a crime", "legal determination of one or another type of actions (inaction) as a crime", "their attribution to crimes"8; "legal recognition of one or another deed as crimes, imposition of criminal liability for them" "9; the field of criminal policy which is in detection of socially dangerous forms of individual behavior, recognition of permissibility, ability and reasonableness of their criminal-legal ban by their consolidation in law as criminal and criminal-punishable ${ }^{10}$. The analysis of scientific works proves that the determination of "criminalization" concept has not been changed over the years. The most successful interpretation was given by P.L. Fris, namely "criminalization is the process of detection of socially dangerous types of human behavior, recognition of the necessity, ability and reasonableness of criminal-legal fighting with them at the state level, and in case of positive response to these issues, their consolidation in law as crimes $^{11 .}$

V. M. Kudriavtsev states that the final stage of criminalization is the criminalization result, namely, a set of criminal law norms contained the list of crimes and punishment provided for them, as well as grounds and conditions for bringing to criminal liability of those guilty or released

\footnotetext{
${ }^{4}$ Кузнецов А. В. Научная основа и информационная база советской уголовной политики. Bonpocbl совершенствования уголовно-правового регулирования: межвуз. сб. науч. тр. Свердловск: Изд-во СЮИ, 1988. С. 8-9.

5 Эффективность уголовно-правовых мер борьбы с преступностью / под ред. Б. С. Никифорова. М.: Юрид. лит., 1968. 256 с.

${ }^{6}$ Дагель П. С. Уголовная политика: управление борьбой с преступностью. Проблемы социологии уголовного права. М., 1984. С. 37-43.

7 Загорный А. В., Ревин В. П. Развитие основных положений уголовной политики: науч.-практ. обзор. М.: Акад. МВД СССР, 1985. 182 с.

8 Босхолов С. С. Основы уголовной политики. Конституционный, криминологический, уголовноправовой и информационный аспекты. М.: «ЮрИнфоР», 1999. 301 с.

${ }^{9}$ Кримінальне право України. Загальна частина: підручник / Ю. В. Александров, В. І. Антипов, М. В. Володько та ін. 3 вид., перероб. та допов. / за ред. М. І. Мельника, В. А. Клименка. Київ: Юридична думка, 2004. 352 с. URL: http://ukrkniga.org.ua/ukrkniga-text/books/_book-697.htm.

${ }_{10}$ Митрофанов А. А. Основні напрямки кримінально-правової політики в Україні: формування та реалізація: автореф. дис. ... канд. юрид. наук. Київ, 2005. 22 с.

${ }^{11}$ Фріс П. Л. Кримінально-правова політика України: дис. ... д-ра юрид. наук. Київ, 2005. 331 с.
} 
from it" $"$. In our opinion, the distinction of the "criminalization result" as an independent stage has no sense since "the consequence" of criminalization is the consolidation of socially dangerous deed in the CC of Ukraine.

\section{Terminology and the System of Factors of Social Conditionality of Criminal Liability}

The terminology of "social conditionality of criminal liability" is traditional in national doctrine of criminal law. However, a different system and terminology of social conditionality of legal norms are used. Some scholars think that these are causes ${ }^{13}$, other - means $^{14}$, grounds ${ }^{15}$, criteria $^{16}$, principles ${ }^{17}$, as well as factors ${ }^{18}$. Using terminology for establishment of social conditionality of criminal liability it is necessary to take into account that the term "criterion" is more common for subject's evaluative activity and it is used as a measure of evaluation; the term "condition" has criminological orientation at studying criminality determinants; the term "ground" is the basic, anything can be based on it, or something by which deeds, behavior etc. is explained" "19; the term "means" in the theory of criminal law is used as optional feature of objective side of the crime composition, these are "subjects, documents, substances, by use of which the conditions for crime are created" 20 . Thus, sharing V. I. Osadchy's opinion we use the term "factors" to stipulate the social conditionality of crimes against person's health.

\footnotetext{
12 Кудрявцев В. Н. Основания уголовно-правового запрета: криминализация и декриминализация. М.: Наука, 1982. 304 с.

13 Гороховська О. В. Кримінальна відповідальність за вбивство через необережність: автореф. дис. ... канд. юрид. наук. Київ, 2003. 18 с.

${ }_{14}$ Орлеан А. М. Соціальна обумовленість криміналізації та кримінально-правова характеристика торгівлі людьми: автореф. дис. ... канд. юрид. наук. Харків, 2003. 20 с.

${ }^{15}$ Кириченко Ю. В. Кримінальна відповідальність за викрадення електричної або теплової енергії: автореф. дис. ... канд. юрид. наук. Дніпропетровськ, 2009. 20 с.

16 Миколенко О. М. Теоретичні основи дослідження шкоди, заподіяної злочином: автореф. дис. ...канд.. юрид. наук. Харків, 2005. 19 с.

17 Омельчук О. М. Контрабанда за кримінальним правом України: автореф. дис. ... канд. юрид. наук. Київ, 2002. 20 с.

18 Осадчий В. І. Проблеми кримінально-правового захисту правоохоронної діяльності: автореф. дис. ... д-ра юрид. наук. Київ, 2004. 36 с.; Доляновська I. М. Кримінальна відповідальність за експлуатацію дітей (аналіз складу злочину): автореф. дис. ... канд. юрид. наук. Київ, 2008.18 с.; Міщук І. П. Кримінально-правова охорона життя та здоров'я захисника чи представника особи: автореф. дис. ... канд. юрид. наук. Київ, 2012. 20 с.

19 Новий тлумачний словник української мови: у 4 т. / укл. В. В. Яременко, О. М. Сліпушко. T. 1. Київ: Аконіт, 2000. 910 с.

${ }^{20}$ Науково-практичний коментар Кримінального кодексу України / за ред. М. І. Мельника, М. І. Хавронюка. 9-те вид., переробл. та доповн. Київ: Юридична думка, 2012. 1316 с.
} 
As the result of analysis of scientific achievements it is possible to make a conclusion that at present an active research is being carried out on the problem of social conditionality of criminal liability. In particular, such system of factors is distinguished:

1) Criminological, regulatory, social-economic, international and historical $^{21}$;

2) Criminal-legal, criminological, regulatory, historical, international, procedural and criminalistic, organizational, socio-psychological ${ }^{22}$;

3) Socio-economic; medical, regulatory, criminological $^{23}$;

4) Historical; regulatory-legal; international-legal; criminological $^{24}$;

5) General social, specific-criminological, criminal-legal ${ }^{25}$;

6) Social, socio-economic, systematic-legal ${ }^{26}$;

7) Criminological, international, historical, regulatory-legal ${ }^{27}$;

8) Historical, criminological, regulatory-legal, international, sociopsychological $^{28}$;

9) Criminological, historical, regulatory socio-psychological, international ${ }^{29}$.

As results of the comparison of the studies mentioned have shown, the authors studying the social conditionality do not follow certain rules, namely: some of them study historical or international factors, others do not do that. There is no a single system and terminology, namely: the scholars use international and international-legal factors as synonymic ones.

21 Белова О. I. Кримінально-правова характеристика системи злочинів проти сім’ї та неповнолітніх: автореф. дис. ... канд. юрид. наук. Київ, 2007. 19 с.

22 Гороховська О. В. Кримінальна відповідальність за вбивство через необережність: автореф. дис. ... канд. юрид. наук. Київ, 2003. 18 с.

23 Гринчак С. В. Порушення встановленого законом порядку трансплантації органів або тканин людини: підстави кримінальної відповідальності: автореф. дис. ... канд. юрид. наук. Харків, 2007. 20 с.

${ }^{24}$ Копотун I. М. Громадський порядок як об'єкт кримінально-правової охорони: автореф. дис. ... канд. юрид. наук. Київ, 2008. 20 с.

25 Литвин О. П. Кримінально-правова охорона громадської безпеки і народного здоров'я: автореф. дис. ... д-ра юрид. наук. Київ, 1999. 46 с.

26 Омельчук О. М. Контрабанда за кримінальним правом України: автореф. дис. ... канд. юрид. наук. Київ, 2002. 20 с.

27 Осадчий В. І.Проблеми кримінально-правового захисту правоохоронної діяльності: автореф. дис. ... д-ра юрид. наук. Київ, 2004. 36 с.

28 Швидченко І. Г. Свобода віросповідання як об'єкт кримінально-правової охорони: автореф. дис. ... канд. юрид. наук. Київ, 2009. 19 с.

${ }_{29}^{29}$ Міщук І. П. Кримінально-правова охорона життя та здоров'я захисника чи представника особи: автореф. дис. ... канд. юрид. наук. Київ, 2012. 20 с. 


\section{Groups of Factors of Social Conditionality of Criminal Liability for Crimes against Person's Health}

Studying the issues on social conditionality of criminal liability for crimes against person's health (Articles 121-128, 130, 133 of CC of Ukraine), we should pay attention on:

1) General factors defining the social conditionality of criminal liability for crimes against person's health, to which we attribute: general social, medical, and socio-economic;

2) Legal factors, arising from legal acts directly - these are historiclegal, internal-legal and regulatory;

3) Criminal-sectoral factors - criminal-legal and criminological.

The analysis of these factors, in our opinion, is sufficient for determination of social conditionality of criminal liability for crimes against person's health.

\subsection{General Factors of Social Conditionality of Criminal Liability for Crimes against Person's Health}

General social factors justify public necessity and political reasonableness of determination of criminal liability for crimes against person's health.

Changes taking place in political, economic and social domains of our state determine the studying of the issue on formation, improvement of law in the field of person's health protection. Unstable society conditions in the field of economics cause violation of human constitutional rights and freedoms, including infringement of person's health. Political and social domains in Ukraine, intensification of global economic crisis facilitate dissemination of crimes not only at the territory of our state but outside its boundaries too. In addition to political, social factors, health protection is influenced by religion and morality belonging to general social factors.

Some religions in the written sources determine certain banscommandments. Studying this issue it has been defined that these "bans" is established in basic world religions and religion movements: Orthodoxy, Buddhism, Judaism; the provision of Islam do not provide for $\mathrm{it}^{30}$. Thus, for example, Biblical commandments mention "do not

\footnotetext{
${ }^{30}$ Ідейні джерела ісламу. URL: http://www.info-works.com.ua/all/religia/3983.html
} 
kill",31, "do not do harm to any living thing" (Buddhism) ${ }^{32}$, Judaism supports the same position ${ }^{33}$. According to Biblical commandment, life and health are interconnected categories which are complementary to each other; this is unconditional indisputable fact. Buddhism has a kind of other taboo, the essence of which is in ban to infringe not only on person's life and health but also on anything (animals etc.). "Definitely, law enforcement as an official activity of state authorities carrying out "here and now", within the limits of actual existing political system, can not in any case ignore such morality that is officially declared by dominating public groups" ${ }^{34}$.

Both nature of social consciousness and state of public opinion depend on moral principles of society. So, social, economic, political processes in society, low level of moral culture and increase in number of religion groups of aggressive purpose influences the grounds and conditions of infringements on person's health and other crime deeds.

Medical factors play special role as well, determining socially the criminal liability for crimes against person's health in a high degree, including physical injury (Articles 121-125), blows and torments (Article 126), tortures (Article 127) etc. Consequences caused by such crimes influence the qualification of deeds of a guilty person. To determine the type of physical injury it is necessary to have special knowledge in the field of forensic medicine. So, such issues of legal and medical nature is described in the Regulations on forensic medicinal determination of the severity degree of physical injuries, the Procedure on organization and carrying out medical social expertise of working capacity loss, the Regulations on carrying out forensic medical expertise (examination) on sexual conditions in bureau of forensic medical expertise, the Criteria of determination of lasting working capacity in percents, the peculiarities of employment of ill and disable people, the Instruction on group of disability determination etc.

Thus, social necessity determines the reasonableness for maintaining criminal liability for crimes committed by a guilty person. The right idea

\footnotetext{
${ }^{31}$ Базалук О. О., Юхименко Н. Ф. Філософія освіти: навч.-метод. посіб. Київ: Кондор, 2010. 164 с. URL: http://pidruchniki.ws/12090810/filosofiya/zolote_pravilo_morali_yogo_vpliv_rozvitok_filosofiyi_osviti.

${ }^{32}$ Кислюк К. В., Кучер О. М. Релігієзнавство: підручник. 5 вид., виправ. і доп. Київ, 2009. 636 с. URL: http://pidruchniki.ws/17670921/religiyeznavstvo/religiyniy_kult_religiyna_organizatsiya_buddizmu.

${ }_{33}^{33}$ Вікіпедія. Вільна енциклопедія. URL: http://ru.wikipedia.org/.

34 Рабінович С. Суспільна мораль як предмет етики й юриспруденції. Право України. 2011. № 8. C. 173-179. URL: http://www.info-pressa.com/article-1201.html.
} 
is that "a crime for some people is the provision of high social and material status, and for others - survival, protection of own rights and interests, and for some people - a protest" ${ }^{35}$. That is why the presence of norms in the $\mathrm{CC}$ of Ukraine providing criminal liability for crimes against person's health, is determined by a medical cause too.

In the case of causing severe physical injury, the person is done certain harm - loss of any organ or its functions, mental illness or other health disorder, combined with a lasting loss of working capacity on at least one third, or abortion or irrecoverable mutilation of face. Therefore, a person loses or may lose the possibility of social activity in society as a personality in full meaning. This may be a precondition for the loss of the main place of work and, consequently, loss of wages; changes in family status, etc. In such case, the state is obliged to provide financial support to these persons or persons taking care of them. "Financial provision of measures for the social protection of disabled people and children with disabilities is carried out at the expense of the state budget, including the Social Protection Fund for Disabled Persons, local budgets, as well as local self-government bodies by local social protection programs for certain categories of people at the expense of local budgets (Article 10). Material, social household and medical care of disabled persons are carried out in the form of cash payments (pensions, benefits, single payments), provision of medicines, technical and other means, including printed publications with a special font, sound amplifiers and analyzers, as well as by providing services on medical, social, labor and professional rehabilitation, household and commercial services (Article 36)." The provisions of the Law of Ukraine "On the Fundamentals of Social Protection of the Disabled persons in Ukraine" are in line with the provisions of the Convention on the Rights of Disabled Persons, which states that "States-members undertake to ensure and promote the full exercise of all human rights and fundamental freedoms by all disabled persons without discrimination regardless any kind of disability". That is why we can also distinguish socio-economic factors, along with the medical cause on this example.

\footnotetext{
35 Джужа О. М., Кирилюк А. В. Кримінологічна експертиза як засіб удосконалення законотворчого процесу. Боротьба з організованою злочинністю і корупиією (теорія і практика). 2003. № 8. URL: http://mndc.nainau.kiev.ua/Gurnal/8text/g8_16.htm.
} 


\subsection{Legislative Factors of Social Conditionality of Criminal Liability for Crimes against Person's Health}

Historical and legal factors arise from studies of the development of national legislation on criminal liability for crimes against person's health. The formation of Ukrainian criminal law from the beginning of the $20^{\text {th }}$ century was accompanied by the adoption of codified acts on criminal liability, in particular the Criminal Code of the USSR in 1922, 1927, the USSR in 1960 and of Ukraine in 2001.

Taking into account the comparative legal characteristics of these codes, it is possible to further formulate the relevant theoretical suggestions for improving the criminal legislation of Ukraine. Therefore, in the current Criminal Code of Ukraine, comparing to previous national Criminal Codes, the level of health protection of a person has been significantly increased, new socially dangerous deeds have been criminalized, and some features of physical injury have been specified.

Adoption of criminal legal norms proves that the state, for reasons of social necessity, makes decisions on the establishment of certain socially dangerous bans. Therefore, the conditionality of criminal liability is the inclusion of a certain norm in the Criminal Code of Ukraine aimed at protecting public relations from crimes. One of these preconditions is the international legal factors, namely: country's obligation to implement international norms and standards ratified by Ukraine in national legislation, having taking liabilities for their observance.

Person's life and health require mandatory protection not only at the national level, but also at the international one. That is why the Constitution of Ukraine stipulates one of the most important provisions in Article 9: "The current international treaties, the consent of which is given by the Verkhovna Rada of Ukraine, is a part of Ukrainian national legislation. The conclusion of international treaties contradicting the Constitution of Ukraine may only be made only after the introduction of appropriate amendments to the Constitution of Ukraine. For the recognition of an international document as internal legislation of Ukraine, the consent of Verkhovna Rada of Ukraine is required. So, Article 9 of the Law of Ukraine "On International Treaties of Ukraine" states about ratification of international treaties by the Verkhovna Rada of Ukraine. In accordance with this Law (Clause b of Part 2, Article 9), international treaties of Ukraine, related to the rights and freedoms and 
duties of a person and a citizen, shall be ratified. In connection with it, there are some international acts in Ukraine aimed at the protection of person's health from unlawful infringements.

International legal factors were also one of the preconditions for criminal liability for any inequality among people. So, for the fulfillment of its international obligations, the Law of Ukraine "On Amendments to the Criminal Code of Ukraine on Liability for Crimes Against Racial, National or Religious Intolerance" as of November 5, 2009 was amended with the disposition of articles providing for criminal liability for crimes against person's health, in particular: Article 121, Article 122, Article 126 and Article 127 of the Criminal Code of Ukraine - "on motives of racial, national or religious intolerance."

So, as the results of international legislation analysis have shown, Ukraine, in general, has provided for criminal-legal norms aimed at person's health protection and they meet European and world standards in this field.

After the proclamation of independence in 1991, Ukraine took a path of democratic society development based on the principles of the supremacy of law and respect for human rights. Conditions are being created for effective legal protection of human rights and fundamental freedoms, as well as guarantees for their full and practical implementation. One of these conditions was the creation and adjustment of national legislation to international legal acts ratified by Ukraine. That is why the state policy was aimed at the adoption of new laws as a regulatory factor of criminal liability for committing crimes against person's health. Under the regulatory factor providing legal protection of person's health, the system of national legal norms regulating public relations in the field of person's health protection is recognized.

In our point of view, it is necessary to distinguish regulatory factors from international ones, since the international legal factor is the basis for determining the social conditionality of criminal liability for crimes against person's health in accordance with the provisions of a wide range of legal international acts. Regulatory factors are determined by a system of normative acts adopted and in force at the territory of Ukraine in accordance with the provisions of the Constitution and current international legal acts, but are determined by us as an independent factor. 
"The process of emergence of new laws (including criminal ones) has cognition of objective patterns of social development, studying the needs of life, practices as its precondition" $"$. Today, there is a wide range of laws governing and protecting public relations in the field of person's health protection.

\subsection{Criminal-Sectoral Factors Socially Determining the Criminal Liability for Crimes against Person's Health}

Criminal law factors The peculiarity of criminal legal norm adoption and its subsequent effectiveness, first of all, depends on its scientific justification and its compliance with the interests of society and the state. For this very reason the study of conditionality of criminal-legal protection of person's health is significant as providing the interests of society, which subsequently finds implementation in the law. "The process of legal norm genesis can be conditionally represented as follows: public relations - living conditions - needs - interests - goals - the will of a lawmaker - the norm"37.

We suggest distinguishing these factors from criminological ones because studying the criminal legal factors it is necessary to analyze criminal-legal categories, namely, such categories that are typical of the criminal law itself, but not criminology.

Some scholars call the following criminal-legal factors: "a) the degree of social danger of deeds; b) the presence of features, which allow determining the homogeneity of criminal deeds; c) the possibility of influencing the deeds by criminal-legal measures; d) implementation of international criminal legal norms in the national legislation" 38 . Others: "the degree of social danger of the deed", "the state of normative legal regulation", «the possibility of influence on the actions by criminal-legal measures" заходами»"; "Negative consequences (social price), in which

\footnotetext{
36 Пащенко О. О. Щодо соціальної обумовленості закону про кримінальну відповідальність: постановка проблеми. Теоретичні та прикладні проблеми сучасного кримінального права: матеріали II міжнар. наук.-практ. конф. (м. Луганськ, 19-20 квіт. 2012 р.) / упоряд.: С. О. Письменський, Ю. Г. Старовойтова. Луганськ: РВВ ЛДУВС ім. Е. О. Дідоренка, 2012. С. 402.

${ }^{37}$ Грищук В. К. Проблеми кодифікації кримінального законодавства України: монографія. Львів: Львів. ун-т, 1993. 173 с.

38 Гороховська О. В. Кримінальна відповідальність за вбивство через необережність: автореф. дис. ... канд. юрид. наук. Київ, 2003. 18 с.

39 Слуцька Т. І. Кримінальна відповідальність за перевищення влади або службових повноважень: дис. ... канд. юрид. наук. Київ, 2010. 232 с.
} 
its social danger is manifested and those characterize its social essence" ${ }^{\text {40; }}$; or "social danger"," "the degree of social danger" differences in determination of criminal-legal factors, it is necessary to emphasize the unanimity of scientists' opinions regarding the distinguishing of a "social dangerousness degree" and "social danger" of a specific deed. The terms "social danger" and "social dangerousness degree" as the basic features of crime were studied by many scientists, including criminologists: A. Andrushko, O. M. Mykolenko, V. I. Smirnov, V. V. Shablysty, N. S. Yusikova and at al. At the same time we emphasize on these terms as fundamental factors of criminal liability for crimes against person's health.

Having studied various points of view on understanding of social dangerousness, V. S. Kovalsky differentiated the basic ones: "1) this is the ability to cause actual damage to a law-enforced object or create a threat of causing such damage; 2) the presence of such damage (real or potential) is estimated from the standpoint of the whole society, but not a specific victim. For this reason the danger is called social; 3) the damage is so big that it threatens fundamental public values, poses a danger to them ${ }^{43}$. The social danger of a crime is characterized by two indicators: its nature (it is a qualitative criterion (qualitative feature), depending on significance (public value) of the object of crime, and the degree (quantitative criterion (quantitative feature), and is determined by the characteristic of particular infringement, by the place, the way, the situation of its commission, availability of certain tools, a degree of implementation of criminal intent, and by the number of victims, etc.

In addition, scholars include the following factors to the criminallegal ones: "1) a significant degree of social dangerousness of this deed; 2) the negative dynamics of growth of these deeds; 3) the necessity of criminal-legal support of a constitutional guarantee; 4) the presence of reasons and conditions of committing a crime that can not be eliminated

\footnotetext{
40 Мельник М. І. Кримінологічні та кримінально-правові проблеми протидії корупції: автореф. дис. ... д-ра юрид. наук. Київ, 2002. 33 с.

41 Доляновська І. М. Кримінальна відповідальність за експлуатацію дітей (аналіз складу злочину): автореф. дис. ... канд. юрид. наук. Київ, 2008. 18 с.

42 Орлеан А. М. Соціальна обумовленість криміналізації та кримінально-правова характеристика торгівлі людьми: автореф. дис. ... канд. юрид. наук. Харків, 2003. 20 с.

${ }^{43}$ Українське кримінальне право. Загальна частина: підручник / за ред. В. О. Навроцького. Київ: Юрінком Інтер. 2013. 712 с.
} 
without the implementation of criminal liability",44, as well as "the presence of socially dangerous deeds, the degree of social danger of deeds, identifying sufficiency of features with crimes in this field, reality of criminal-legal influence on deeds" $" 45$. Thus, the material feature of any crime, including crimes against person's health, is social dangerousness of a deed that causes or is likely to cause harm to person's health.

According to the above mentioned, there is no single point of view on determining the conditionality of criminal liability through the prism of criminal-legal factors among the scholars at present. The conditionality of criminal-legal factors is determined by social dangerousness of crimes against person's health. The previous Criminal Codes (1922, 1927 and 1960) contained articles defining responsibility for socially dangerous unlawful deeds that did harm to person's health, with certain stylistic differences.

In our opinion, the criminal-legal factors defines the determination of criminal liability for crimes against person's health, inherent only in this field of law by way of formulation of articles in dispositions, as well as formulation of sanctions as generalized types and amount of penalties for these socially dangerous deeds.

Criminological factors At present, there are some problems as for differentiation of criminal legal and criminological factors. This is caused by the fact that scholars (O. O. Pashchenko, M. G. Zaslavska) state that criminological factors determine that the main reason for criminalization of a deed is its social dangerousness, the extent of which is influenced by public value of these public relations or social properties of consequences, caused by this deed. In our opinion, these features are precondition for criminal-legal factors, since they are widely used by both a theory of criminal law and criminology, and therefore they may belong to criminological factors.

The best suggestions are of O.V. Gorokhovska and V. A. Myslyvy, who researching criminological factors of a certain crime (crimes) suggest distinguishing: "a) large spreading of a kind of infringement analyzed;

\footnotetext{
${ }^{44}$ Кириченко Ю. В. Кримінальна відповідальність за викрадення електричної або теплової енергії: автореф. дис. ... канд. юрид. наук. Дніпропетровськ, 2009. 20 с.

45 Мисливий В. А. Злочини проти безпеки дорожнього руху та експлуатації транспорту (кримінально-правове та кримінологічне дослідження): автореф. дис. ... д-ра юрид. наук. Київ, 2005. $36 \mathrm{c}$.
} 
b) a level, structure and dynamics: c) reasons and conditions" 46 , as well as "wide-spread nature of deeds subjected to criminalization, a level, structure, dynamics of such torts, a guilty person, a scope of caused harm, reasons and conditions contributed to torts, prediction of reasonableness of deed criminalization" 47 .

Therefore, in order to outline the criminological factors, it is necessary to establish the status, structure and dynamics of crimes against person's health, preceded the adoption of the Criminal Code of Ukraine in 2001.

According to the statistical data analysis of the Department of Information and Analytical Support of the Ministry of Internal Affairs of Ukraine on the number of crimes against person's health in Ukraine for the period of 1997-2000, the conclusion can be made that the structure of crime constitutes intentional grave physical injury (Article 101 of the Criminal Code of 1960) Thus, during 1997, in comparison with other crimes against person's health, $43.88 \%$ were brought to criminal liability; in $1998-38.62 \%$; in $1999-41.11 \%$; in $2000-41.42 \%$.

The structure of crimes of intentional physical injury of middle gravity (Article 102 of the Criminal Code of 1960), compared with other crimes against person's health is as follows: for $1997-43.88 \%$; $1998-$ $47.2 \%$; $1999-46.55 \% ; 2000-46.69 \%$.

The structure of crimes of intentional grave or physical injury of middle gravity caused in a state of intense emotional distress (Article 103 of the Criminal Code of 1960), as compared with other crimes against person's health is as follows: for $1997-0.7 \%$; $1998-0.71 \%$; $1999-$ $0.5 \% ; 2000-0.47 \%$.

The structure of crimes of intentional grave physical injury in excess of the boundaries of necessary defense (Article 104 of the Criminal Code of 1960), compared with other crimes against person's health is as follows: for $1997-1.4 \% ; 1998-1.49 \% ; 1999-1.33 \% ; 2000-1.28 \%$.

The structure of crimes of careless grave or physical injury of middle gravity (Article 105 of the Criminal Code of 1960), as compared with other crimes against person's health is as follows: for $1997-3.59 \%$; $1998-4.15 \% ; 1999-4.04 \% ; 2000-3.5 \%$.

\footnotetext{
46 Гороховська О. В. Кримінальна відповідальність за вбивство через необережність: автореф. дис. ... канд. юрид. наук. Київ, 2003. 18 с.

${ }^{47}$ Мисливий В. А. Злочини проти безпеки дорожнього руху та експлуатації транспорту (кримінальноправове та кримінологічне дослідження): автореф. дис. ... д-ра юрид. наук. Київ, 2005. 36 с.
} 
The structure of crimes of intentional trivial physical injury (Article 106 of the Criminal Code of 1960), compared with other crimes against person's health is as follows: for $1997-4.9 \% ; 1998-5.96 \%$; $1999-5.26 \% ; 2000-5.44 \%$.

The structure of crimes of blows and torments (Article 107 of the Criminal Code of 1960), as compared with other crimes against person's health is as follows: for $1997-0.7 \% ; 1998-0.82 \% ; 1999-0.57 \%$; $2000-0.59 \%$.

The structure of crimes on contamination with sexually transmitted infections (Article 108 of the Criminal Code of 1960), as compared with other crimes against person's health is as follows: for $1997-0.82 \%$; $1998-0.81 \% ; 1999-0.52 \% ; 2000-0.44 \%$.

The structure of crimes of contamination with the human immunodeficiency virus (Article 108-2 of the Criminal Code of 1960), compared with other crimes against person's health is as follows: for $1997-0.07 \% ; 1998-0.2 \% ; 1999-0.08 \% ; 2000-0.12 \%$. Table 1.1. shows the dynamics of crimes against person's health (in percentages) during 1997-2000.

Table 1.1

\begin{tabular}{|c|c|c|c|c|}
\hline \multirow{2}{*}{$\begin{array}{c}\text { Article } \\
\text { number }\end{array}$} & \multicolumn{4}{|c|}{ Years } \\
\cline { 2 - 5 } & $\mathbf{1 9 9 7}$ & $\mathbf{1 9 9 8}$ & $\mathbf{1 9 9 9}$ & $\mathbf{2 0 0 0}$ \\
\hline 101 & 27.4 & 22.5 & 25.4 & 24.69 \\
\hline 102 & 24.57 & 24.66 & 25.79 & 24.96 \\
\hline 103 & 30.52 & 28.53 & 21.33 & 19.6 \\
\hline 104 & 26.32 & 26.1 & 24.59 & 22.93 \\
\hline 105 & 24.17 & 26.07 & 26.89 & 22.5 \\
\hline 106 & 23.51 & 26.63 & 24.95 & 24.89 \\
\hline 107 & 27.15 & 29.35 & 21.85 & 21.6 \\
\hline 108 & 32.64 & 30.13 & 20.54 & 16.66 \\
\hline $108-2$ & 16.04 & 40.74 & 18.51 & 24.69 \\
\hline
\end{tabular}

Thus, according to statistics on crimes against parson's health, it can be stated that these indicators are a precondition for criminalization of these deeds in the Criminal Code of Ukraine in 2001. During four years (1997-2000 years), the statistical curve is as follows:

Intentional grave physical injury (Article 101 of the Criminal Code of 1960): in 1997, 7,602 was registered, in $1998-6,243$, which is less by $8.6 \%$; in 1998, the curve increased by $17.87 \%$; in 1999 there was a 
decrease of the level to $12.87 \%$ and in 2000 - to $2.76 \%$. So, the indicators of intentional grave physical injury were quantitatively changed in 1998;

Intentional physical injury of middle gravity (Article 102 of the Criminal Code of 1960): in 1997, 7,603 was registered, in 1998 - 7,630, which is less by $0.3 \%$ compared with the previous year; in 1998 - less by $4.58 \%$, compared to 1999 , the indicators increased by $3.12 \%$ and in 2000 - by $6.6 \%$.

Intentional grave or physical injury of middle gravity caused in a state of intense emotional distress (Article 103 of the Criminal Code of 1960): in 1997, 123 was registered, 115 (6.5\%) in 1998; $1999-25.2 \%$; the level of this crime significantly decreased during 1999-2000-6.14\%; $2001-11.39 \%$.

Intentional grave physical injury in excess of the boundaries of necessary defense (Article 104 of the Criminal Code of 1960): in 1997, 244 was registered, in $1998-242$, which is by $0.8 \%$ less than in the previous year, the same tendency was observed in following years: $1999-$ $5.78 \% ; 2000-6.57 \% ; 2001-33.8 \%$.

Careless grave or physical injury of middle gravity (Article 105 of the Criminal Code of 1960): 623 was registered in 1997, in $1998-672$, which is $7.86 \%$ compared to the previous year; $1999-3.12 \%$, and in subsequent years the level of crime has increased significantly: in $2000-$ $16.3 \% ; 2001-11.03 \%$.

Intentional trivial physical injury (Article 106 of the Criminal Code of 1960): in 1997, 815 was registered, in 1998 - 964, that is, the increase of cases by $13.27 \%$, while in subsequent years, the crime rate for this crime has increased: $1999-6.23 \% ; 2000-0.22 \% ; 2001-16.87 \%$.

Blows and torments (Article 107 of the Criminal Code of 1960): 123 was registered in 1997, 133 in 1998, 133 in accordance with the abovementioned data, the level of crime increased by $8.1 \%$, later on the increase in a level of crime has decreased: $1999-25.56 \% ; 2000-1.01 \% ; 2001-$ $16.32 \%$.

Contamination with sexually transmitted infections (Article 108 of the Criminal Code of 1960): in 1997, 143 was registered, in 1998 - 132, which is $7.6 \%$ less than in the previous year; in 1999 the indicators decreased by $31.81 \%$, in 2000 - by $18.88 \%$, and in 2001 - by $87.61 \%$.

Contamination with the human immunodeficiency virus (Article 108-2 of the Criminal Code of 1960): in 1997, 13 cases were registered, in 1998 - 
33 , which is $153.84 \%$ more than the previous one; $1999-54.54 \%$; 2000 : $33.33 \%$; $2001-12.90 \%$.

According to the study results on criminal-legal factors of crimes against person's health causing criminal liability, it is determined that the social dangerousness of these crimes, resulted in harm to person's health, influences criminalization of a deed. The criminological factors of these crimes include those factors that preceded the adoption of the Criminal Code of Ukraine in 2001, so, criminalization of crimes against person's health is affected by the following:

- Spreading of infringements on person's health in society;

- Dynamics of crimes against person's health at the territory of our state;

- The structure and status of the crime - the indicators of crimes against person's health during the time analyzed remain the stable, although, too high.

\section{CONCLUSIONS}

Determination of factors defined the necessity for adoption of some criminal-legal bans is a precondition for criminalization of a certain deed, as a result of which its relevant consolidation in the normative-legal act is carried out, namely in the Criminal Code of Ukraine. For declaration of social conditionality of crimes against person's health, the following factors are distinguished: historical (the development and formation of Ukrainian criminal legislation was carried out by using works of the Criminal Code of the USSR of 1922, 1927, the USSR in 1960), general social (the influence of religion and morality on the formation of social necessity and political reasonableness of establishing criminal liability for crimes against person's health), medical (special knowledge in the field of forensic medicine made it possible to carry out the division of physical injuries according to their types), socio-economic (loss of social activity as a full member of society and budget costs associated with the treatment and rehabilitation of such person), international legal (the adoption of criminal legal norms through the implementation of international norms and standards in national legislation), regulatory (the system of national legal norms regulating public relations in the field of person's health protection), criminal-legal (social dangerousness of crimes and their subsequent formulation in disposition of articles and sanctions as 
generalized types and amount of punishment for those socially dangerous deeds) and criminological (spreading of infringements on person's health in society, their dynamics, structure and status of crimes). As a result of analysis of the indicators of crimes against person's health before adoption of the Criminal Code of Ukraine in 2001 it was established that the indicators are stable, although, too high

\section{SUMMARY}

In the study of the issue on social conditionality of criminal liability for crimes against person's health it is suggested to distinguish: historical, general social, medical, socio-economic, international-legal, regulatory, criminal-legal and criminological factors, the analysis of which is sufficient for determination of social conditionality of criminal liability for crimes against person's health.

\section{REFERENCES}

1. Теорія держави і права. Академічний курс: підручник / за ред. О. В. Зайчука, Н. М. Оніщенко. 2 вид., перероб. і допов. Київ: Юрінком Iнтер, 2008. 688 c. URL: http://www.ebk.net.ua/Book/ law/zaychuk_tdp/part2/401.htm.

2. Соціологія: підручник / Н. П. Осипова, В. Д. Воднік, Г. П. Клімова та ін.; за ред. Н. П. Осипової. Київ: Юрінком Інтер, 2003. 336 c. URL: http://radnuk.info/pidrychnuku/sotsiologiya/507osupova/10927-s-2html/

3. Коржанский Н. Й. Установление вины. Юрид. практика. 1997. № 3 (37). Февраль. С. 5-6.

4. Кузнецов А. В. Научная основа и информационная база советской уголовной политики. Bопросы совершенствования уголовно-правового регулирования: межвуз. сб. науч. тр. Свердловск: Изд-во СЮИ, 1988. С. 8-9.

5. Эффективность уголовно-правовых мер борьбы с преступностью / под ред. Б. С. Никифорова. М.: Юрид. лит., 1968. 256 с.

6. Дагель П. С. Уголовная политика: управление борьбой с преступностью. Проблемь социологии уголовного права. М., 1984. C. $37-43$. 
7. Загорный А. В., Ревин В. П. Развитие основных положений уголовной политики: науч.-практ. обзор. М.: Акад. МВД СССР, 1985. $182 \mathrm{c}$.

8. Босхолов С. С. Основы уголовной политики. Конституционный, криминологический, уголовно-правовой и информационный аспекты. М.: «ЮрИнфоР», 1999. 301 с.

9. Кримінальне право України. Загальна частина: підручник / Ю. В. Александров, В. І. Антипов, М.В.Володько та ін. 3 вид., перероб. та допов. / за ред. М. І. Мельника, В. А. Клименка. Київ: Юридична думка, 2004. 352 с. URL: http://ukrkniga.org.ua/ukrknigatext/books/_book-697.htm.

10. Митрофанов А. А. Основні напрямки кримінально-правової політики в Україні: формування та реалізація: автореф. дис. ... канд. юрид. наук. Київ, 2005. 22 с.

11. Фріс П. Л. Кримінально-правова політика України: дис. ... д-ра юрид. наук. Київ, 2005. $331 \mathrm{c.}$

12. Кудрявцев В. Н. Основания уголовно-правового запрета: криминализация и декриминализация. М.: Наука, 1982. 304 с.

13. Гороховська О. В. Кримінальна відповідальність за вбивство через необережність: автореф. дис. ... канд. юрид. наук. Київ, 2003. $18 \mathrm{c}$.

14. Орлеан А. М. Соціальна обумовленість криміналізації та кримінально-правова характеристика торгівлі людьми: автореф. дис. ... канд. юрид. наук. Харків, 2003. 20 с.

15. Кириченко Ю. В. Кримінальна відповідальність за викрадення електричної або теплової енергії: автореф. дис. ... канд. юрид. наук. Дніпропетровськ, 2009. 20 с.

16. Миколенко О. М. Теоретичні основи дослідження шкоди, заподіяної злочином: автореф. дис. ...канд.. юрид. наук. Харків, 2005. 19 c.

17. Омельчук О. М. Контрабанда за кримінальним правом України: автореф. дис. ... канд. юрид. наук. Київ, 2002. 20 с.

18. Осадчий В. I. Проблеми кримінально-правового захисту правоохоронної діяльності: автореф. дис. ... д-ра юрид. наук. Київ, 2004. 36 c. 
19. Доляновська I. M. Кримінальна відповідальність за експлуатацію дітей (аналіз складу злочину): автореф. дис. ... канд. юрид. наук. Київ, 2008. 18 с.

20. Міщук I. П. Кримінально-правова охорона життя та здоров'я захисника чи представника особи: автореф. дис. ... канд. юрид. наук. Київ, 2012. 20 с.

21. Новий тлумачний словник української мови: у 4 т. / укл. В. В. Яременко, О. М. Сліпушко. Т. 1. Київ: Аконіт, 2000. 910 с.

22. Науково-практичний коментар Кримінального кодексу України / за ред. М. І. Мельника, М. І. Хавронюка. 9-те вид., переробл. та доповн. Київ: Юридична думка, 2012. 1316 с.

23. Белова О. I. Кримінально-правова характеристика системи злочинів проти сім’ї та неповнолітніх: автореф. дис. ... канд. юрид. наук. Київ, 2007. 19 с.

24. Гринчак С. В. Порушення встановленого законом порядку трансплантації органів або тканин людини: підстави кримінальної відповідальності: автореф. дис. ... канд. юрид. наук. Харків, 2007. $20 \mathrm{c}$.

25. Копотун I. М. Громадський порядок як об'єкт кримінальноправової охорони: автореф. дис. ... канд. юрид. наук. Київ, 2008. 20 с.

26. Литвин О. П. Кримінально-правова охорона громадської безпеки і народного здоров'я: автореф. дис. ... д-ра юрид. наук. Київ, 1999. $46 \mathrm{c.}$

27. Швидченко I. Г. Свобода віросповідання як об'єкт кримінально-правової охорони: автореф. дис. ... канд. юрид. наук. Київ, 2009. 19 с.

28. Ідейні джерела ісламу. URL: http://www.info-works.com.ua/ all/religia/3983.html

29. Базалук О. О., Юхименко Н. Ф. Філософія освіти: навч.-метод. посіб. Київ: Кондор, 2010. 164 с. URL: http://pidruchniki.ws/12090810/ filosofiya/zolote_pravilo_morali_yogo_vpliv_rozvitok_filosofiyi_osviti.

30. Кислюк К. В., Кучер О. М. Релігієзнавство: підручник. 5 вид., виправ. і доп. Київ, 2009. 636 с. URL: http://pidruchniki.ws/17670921/ religiyeznavstvo/religiyniy_kult_religiyna_organizatsiya_buddizmu.

31. Вікіпедія. Вільна енциклопедія. URL: http://ru.wikipedia.org/. 
32. Рабінович С. Суспільна мораль як предмет етики й юриспруденції. Право України. 2011. № 8. С. 173-179. URL: http://www.info-pressa.com/article-1201.html.

33. Джужа О. М., Кирилюк А. В. Кримінологічна експертиза як засіб удосконалення законотворчого процесу. Боротьба 3 організованою злочинністю і корупиією (теорія і практика). 2003. № 8. URL: http://mndc.nainau.kiev.ua/Gurnal/8text/g8_16.htm.

34. Пащенко О.О.Щодо соціальної обумовленості закону про кримінальну відповідальність: постановка проблеми. Теоретичні та прикладні проблеми сучасного кримінального права: матеріали II міжнар. наук.-практ. конф. (м. Луганськ, 19-20 квіт. 2012 р.) / упоряд.: Є. О. Письменський, Ю. Г. Старовойтова. Луганськ: РВВ ЛДУВС ім. Е. О. Дідоренка, 2012. С. 402.

35. Грищук В. К. Проблеми кодифікації кримінального законодавства України: монографія. Львів: Львів. ун-т, 1993. 173 с.

36. Слуцька Т. І. Кримінальна відповідальність за перевищення влади або службових повноважень: дис. ... канд. юрид. наук. Київ, 2010. $232 \mathrm{c}$.

37. Мельник M. I. Кримінологічні та кримінально-правові проблеми протидії корупції: автореф. дис. ... д-ра юрид. наук. Київ, 2002.33 c.

38. Українське кримінальне право. Загальна частина: підручник / за ред. В. О. Навроцького. Київ: Юрінком Інтер. 2013. 712 с.

39. Мисливий В. А. Злочини проти безпеки дорожнього руху та експлуатації транспорту (кримінально-правове та кримінологічне дослідження): автореф. дис. ... д-ра юрид. наук. Київ, 2005. 36 с.

\section{Information about the author: Katerynchuk K. V. \\ Candidate of Juridical Sciences,} Assistant Professor at the Department of Special Legal Disciplines of the Educational-Scientific Humanitarian Institute of the V. I. Vernadsky Taurida National University 33, Ivana Kudri str., Kyiv,Ukraine 